Krystyna SKOCZYLAS ${ }^{1}$

\title{
PROCES ZAOPATRZENIA W PRZEDSIĘBIORSTWIE HANDLOWYM
}

Artykuł dotyczy problematyki procesu zaopatrzenia towarowego $\mathrm{w}$ przedsiębiorstwie handlowym. Omówiono w nim główne zadania procesu zakupu oraz występujące w nim problemy decyzyjne. Przedstawiono również strategie zaopatrzenia stosowane przez przedsiębiorstwa.

Słowa kluczowe: zaopatrzenie, problemy decyzyjne, zadania procesu zakupu, strategie.

\section{WPROWADZENIE}

Dążeniem każdego przedsiębiorstwa, nie tylko handlowego, jest maksymalne zaspokojenie potrzeb klienta. Obecnie to on jest najważniejszy w strategii działania każdego przedsiębiorstwa. Tylko takie postępowanie pozwala na utrzymanie stałych oraz przyciągnięcie nowych klientów. Drugim istotnym czynnikiem wpływającym na funkcjonowanie przedsiębiorstwa jest wzmożona konkurencja. To ona motywuje przedsiębiorstwa do podejmowania ciągle nowych działań warunkujących ich przetrwanie i rozwój. Przewagę nad konkurencją może zapewnić właściwe zarządzanie. Wymaga ono z kolei wiarygodnych i szybkich informacji, różnego typu analiz oraz podpowiedzi wynikających z rachunku ekonomicznego. W przedsiębiorstwach handlowych szczególnie istotne jest zarządzanie procesem zaopatrzenia w towary. Racjonalizacja procesu zakupu prowadzi bowiem do efektywniejszego działania przedsiębiorstw ${ }^{2}$. Wpływ nie tylko na finansowanie bieżącej działalności przedsiębiorstwa, ale i na jego rozwój i postęp ${ }^{3}$. Przedsiębiorstwa handlowe zmuszone są więc do prowadzenia właściwej polityki zakupów. Wynika to z tego, że najwięcej środków finansowych angażują właśnie zapasy towarów. Rośnie znaczenie planowania i kontroli całego procesu zaopatrzeniowego. Można więc stwierdzić, że właściwie prowadzone działania logistyczne to obecnie jeden z ważniejszych czynników mających wpływ na prawidłowe funkcjonowanie przedsiębiorstwa.

Celem artykułu jest przedstawienie głównych zadań w procesie zaopatrzenia oraz scharakteryzowanie podstawowych strategii zakupu.

\footnotetext{
${ }^{1}$ Dr Krystyna Skoczylas, Zakład Finansów i Bankowości, Politechnika Rzeszowska.

${ }^{2}$ W. Szczepankiewicz, Organizacja źródet zaopatrzenia i rola handlu detalicznego $w$ kanałach rynku, [w:] Handel detaliczny. Funkcjonowanie i kierunki rozwoju, red. J. Szumilak, Oficyna Ekonomiczna, Kraków 2004, s. 142.

${ }^{3}$ Cz. Skowronek, Wplyw procesów zaopatrzenia i gospodarowania materiałami na wyniki ekonomiczne przedsiębiorstwa, Gospodarka Materiałowa i Logistyka 1997/1, s. 5.
} 


\section{ZADANIA I PROBLEMY DECYZYJNE W PROCESIE ZAOPATRZENIA}

Proces zaopatrzenia (zakupu) można zdefiniować jako część procesu logistycznego, w którym następuje zasilenie w potrzebne towary ${ }^{4}$. Roger Cox i Paul Brittain definiują zakup jako ,proces wykonania decyzji podyktowanych filozofią kupiecką”. Jest on niezmiernie ważny, ponieważ wpływa na:

- racjonalizację obrotu towarowego przez akceptację określonego poziomu i wielkości kosztów związanych z zaopatrzeniem towarowym;

- poziom obsługi klienta;

- stopień niezależności detalisty od dostawców towarów ${ }^{5}$.

Organizacja procesu zaopatrzenia ma więc na celu minimalizację kosztów i równoczesne zachowanie prawidłowych dostaw i zapasów magazynowych ${ }^{6}$.

W procesie zakupu przedsiębiorstwo handlowe podejmuje działania o charakterze zarówno strategicznym, jak i operacyjnym. Pierwsze z nich dotyczą dłuższego przedziału czasowego (kilka lat). Obejmują głównie identyfikację, znalezienie i wykorzystanie źródeł zaopatrzenia, korzystnych z punktu widzenia kosztów. Obecnie czasie niezbędne staje się również uwzględnienie czynników związanych z ekologią czy czasem ${ }^{7}$.

Problemy na poziomie operacyjnym dotyczą bieżącej organizacji przepływów fizycznych w celu minimalizacji kosztów, zapewnienia właściwej gospodarki magazynowej, korzystniejszego środka transportu towarów oraz uzyskania wysokiego stopnia gotowości do realizacji zamówień ${ }^{8}$.

Tabela. 1. Zadania procesu zaopatrzenia

\begin{tabular}{|c|c|}
\hline \multicolumn{2}{|c|}{ Zaopatrzenie } \\
\hline $\begin{array}{c}\text { Proces zakupu } \\
\text { obejmuje następujące działania: }\end{array}$ & $\begin{array}{l}\text { Logistyka procesu zaopatrzenia } \\
\text { obejmuje następujące działania: }\end{array}$ \\
\hline $\begin{array}{l}\text { Badanie rynku dostawców } \\
\text { Porównanie oferowanych przez dostawców } \\
\text { warunków dostawy, szczególnie cen } \\
\text { Wybór najkorzystniejszego dostawcy } \\
\text { Zawarcie umowy z wybranym dostawcą } \\
\text { Realizacja zawartej umowy } \\
\text { Zarządzanie działaniami występującymi w } \\
\text { obszarze zakupu }\end{array}$ & $\begin{array}{l}\text { Przyjęcie oraz przeprowadzenie kontroli } \\
\text { dostawy } \\
\text { Przemieszczenie dostawy za pomocą } \\
\text { środków transportu wewnętrznego } \\
\text { Składowanie dostarczonego towaru w } \\
\text { przeznaczonym do tego celu miejscu } \\
\text { Utrzymywanie właściwych stanów } \\
\text { magazynowych } \\
\text { Kierowanie działaniami magazynowymi } \\
\text { Planowanie, sterowanie i kontrola } \\
\text { przepływów rzeczowych i informacji }\end{array}$ \\
\hline
\end{tabular}

Źródło: opracowanie własne na podstawie W. Szczepankiewicz, Obsługa logistyczna sektora handlu. Uwarunkowania i kierunki zmian, Wydawnictwo Akademii Ekonomicznej w Krakowie, Kraków 2002, s. 94.

\footnotetext{
${ }^{4}$ Cz. Skowronek, Z. Sarjusz - Wolski, Logistyka w przedsiębiorstwie, PWE, Warszawa 1999, s. 108.

${ }^{5}$ W. Szczepankiewicz, op. cit., s. 123.

${ }^{6}$ M. Nowicka - Skowron, Efektywność systemów logistycznych, PWE, Warszawa 2000, s.34

${ }^{7}$ P. Blaik, Logistyka. Koncepcja zintegrowanego zarzqdzania, PWE, Warszawa 2001, s.134.

${ }^{8}$ M. Maternowska, Analiza kosztów logistycznych wspomaga proces podejmowania decyzji w sferze dystrybucji

- studium przypadków, Logistyka, 2002/4, s. 18-20.
} 
Jak wiadomo, głównym zadaniem zakupu jest dostarczenie towarów w celu zaspokojenia potrzeb finalnego odbiorcy w wymaganej przez niego ilości, jakości, w odpowiednim czasie i po najniższych kosztach ${ }^{9}$. Realizacja tego celu wymaga prowadzenia badań rynku zaopatrzeniowego w celu dokonania wyboru odpowiednich dostawców oraz sposobu realizacji dostawy, a także prowadzenia odpowiedniej polityki zaopatrzenia.

Oprócz wyboru i oceny dostawców ważnym zadaniem jest także planowanie procesów magazynowych i transportu, planowanie struktury zaopatrzenia, miejsc magazynowania, określenie, które towary mają znaczenie strategiczne, a które są ryzykowne, oraz przyjęcie założeń związanych $\mathrm{z}$ systemem informatycznym ${ }^{10}$. Wymienione punkty nie muszą występować w każdym procesie zaopatrzeniowym, ponieważ przedsiębiorcy często korzystają ze znanych sobie i sprawdzonych źródeł zakupu danego towaru. Przestrzeganie tych zadań jest natomiast konieczne w wypadku towarów nowych lub dostawców niesprawdzających się.

Bardzo ważnym zadaniem w procesie zakupu jest określenie optymalnej wielkości dostawy oraz terminu opracowania i wysłania zamówienia na kolejną dostawę. Optymalna wielkość dostawy dla danego towaru to taki rozmiar dostawy, przy którym suma kosztów związanych $\mathrm{z}$ zakupem oraz utrzymaniem zapasów są najmniejsze dla ustalonego okresu. Wielkość tę powinno się obliczać odrębnie dla każdego towaru. Działanie to jest jednak bardzo pracochłonne, dlatego też bardzo pomocny okazuje się tu odpowiedni system informatyczny. Optymalny rozmiar dostawy oraz poziom zapasu opierają się na dziennej sprzedaży. Drugim więc ważnym elementem w polityce zaopatrzenia, oprócz kosztów, jest określenie przyszłej wielkości sprzedaży. Wielkość tę można określić przez prognozowanie dziennej sprzedaży. Prognozowanie wprowadza jednak pewien element prawdopodobieństwa. Należy się więc liczyć z możliwością powstania odchyleń od prognozowanej wielkości sprzedaży towarów na plus lub na minus. W związku z tym, należy jeszcze wprowadzić zapas zabezpieczający przed błędami prognozy. Ustalając optymalną wielkość zakupu, należy uwzględnić ograniczenia wynikające z dostępnej powierzchni magazynowej, warunków magazynowania, sytuacji na rynku zaopatrzeniowym, możliwości finansowych, warunków wynikających $\mathrm{z}$ otoczenia przedsiębiorstwa ${ }^{11}$.

\section{STRATEGIE REALIZOWANE W PROCESIE ZAOPATRZENIA}

W literaturze przedmiotu podaje się dwie przeciwstawne strategie zaopatrzenia ${ }^{12}$. Jedna $\mathrm{z}$ nich oparta jest na umowach krótkookresowych z dostawcami oraz konkurencji, natomiast druga polega na współpracy długookresowej oraz synchronizacji zaopatrzenia i sprzedaży. Charakterystykę obu strategii przedstawiono na rysunku 1.

\footnotetext{
${ }^{9}$ W. Szczepankiewicz, Obstuga logistyczna sektora handlu. Uwarunkowania i kierunki zmian, Wydawnictwo Akademii Ekonomicznej w Krakowie, Kraków 2002, s. 94.

${ }^{10}$ M. Ciesielski, Strategie logistyczne przedsiębiorstw, Wydawnictwo Akademii Ekonomicznej w Poznaniu, Poznań 1998, s. 33

${ }^{11}$ W. Weiss., Integracyjna rola zarzqdzania zapasami, „Logistyka” 2003/1, s. 22.

${ }^{12}$ Szczepankiewicz W., Obstuga logistyczna sektora handlu..., s. 105.
} 
Rys. 1. Strategie zarządzania procesem zakupu w przedsiębiorstwie handlowym

\begin{tabular}{|c|c|}
\hline & $\begin{array}{l}\text { Zalety: } \\
\text { - obniżka kosztów, a tym samym cen, dzięki } \\
\text { współzawodnictwu dostawców, } \\
\text { - wiele źródeł zaopatrzenia, } \\
\text { - niezależność od dostawców. }\end{array}$ \\
\hline $\begin{array}{l}\text { wykorzystuja } \\
\text { konkurencję } \\
\text { pomiędzy } \\
\text { dostawcami }\end{array}$ & $\begin{array}{l}\text { Wady: } \\
\text { - trudności w planowaniu sprzedaży, } \\
\text { - koszty związane z opóźnionymi dostawami, } \\
\text { - konieczność utrzymywania zapasów, } \\
\text { - ponoszenie dodatkowych kosztów w wypadku } \\
\text { zawierania dodatkowych umów na dostawy w } \\
\text { razie większego zapotrzebowania, } \\
\text { - konieczność ciągłej analizy rynku zakupów }\end{array}$ \\
\hline $\begin{array}{l}\text { Strategia } \\
\text { bazująca na } \\
\text { synchronizacji } \\
\text { dostaw z } \\
\text { przebiegiem } \\
\text { procesu }\end{array}$ & $\begin{array}{l}\text { Zalety: } \\
\text { - zaopatrzenie przy minimalnych zapasach, } \\
\text { - niższe koszty utrzymania zapasów, } \\
\text { - możliwość zawierania umów długookresowych } \\
\text { na lepszych warunkach, } \\
\text { - brak konieczności ciągłej analizy rynków } \\
\text { zakupów }\end{array}$ \\
\hline sprzedaży & $\begin{array}{l}\text { Wady: } \\
\text { - ograniczona liczba dostawców, } \\
\text { - konieczność ścisłej współpracy z dostawcami }\end{array}$ \\
\hline
\end{tabular}

Źródło: opracowanie własne na podstawie W. Szczepankiewicz, Organizacja źródet zaopatrzenia i rola handlu detalicznego w kanałach rynku, [w]: Handel detaliczny.

Funkcjonowanie i kierunki rozwoju, red. J. Szumilak, Oficyna Ekonomiczna, Kraków 2004, s. $138-139$.

Przedsiębiorstwa handlowe mogą zawierać z dostawcami umowy długofalowe - ramowe, w celu zapewnienia niezawodności i szybkości dostaw oraz korzystniejszych warunków zakupu. Natomiast w wypadku pojawienia się nowych potrzeb u klientów, ważna jest umiejętność zdobywania szybkich źródeł dostaw. Daje ona przedsiębiorstwu handlowemu przewagę czasową nad konkurencją ${ }^{13}$. Pozwala na szybką reakcję na docierające z rynku informacje dotyczące zapotrzebowań klientów.

Przedsiębiorstwa handlowe bardzo często korzystają z zakupów masowych ${ }^{14}$. Mają one swoje zalety, do których zalicza się ograniczenie ryzyka braku towarów w wypadku niespodziewanego wzrostu popytu, możliwość uzyskania dużych rabatów, proporcjonalnych do ilości kupowanego towaru, obniżenie kosztów zakupu. Wadą zaś,

${ }^{13}$ M. T. Dudzik, Zakup czy produkcja własna?, „Gospodarka Materiałowa i Logistyka” 1997/2, s. 29.

${ }^{14}$ R. Cox, P. Brittain, op.cit., s. 174. 
jest wzrost kosztów utrzymania zapasu. Bardzo pomocnym rozwiązaniem w planowaniu zakupu towarów jest ustalenie najważniejszych pozycji dla przedsiębiorstwa ${ }^{15}$. Niektóre towary cechuje wysoka stopa użytkowania, dlatego w celu zapewnienia właściwego poziomu obsługi klienta nie może takich towarów zabraknąć i powinny być składowane. W wypadku towarów o mniejszym znaczeniu, dostawy mogą być organizowane rzadziej, bądź mogą zostać całkowicie wykluczone z oferty. Niektóre towary z kolei są szczególnie drogie, dlatego ich wysoki poziom zapasu jest bardzo kosztowny ${ }^{16}$. Każde przedsiębiorstwo handlowe powinno ustalić hierarchię ważności towarów wspólnie składowanych, posługując się na przykład metodą ABC. W planowaniu zakupów należy uwzględniać również okres ich trwałości.

$\mathrm{W}$ metodzie $\mathrm{ABC}$ wykorzystuje się zarówno wartość, jak i ilość zapasu towarów ${ }^{17}$. Analizując zapasy metodą $\mathrm{ABC}$ dzieli się je na trzy grupy, tj.:

- towary przypisane do grupy A obejmują 20\% całości zapasu, a stanowią $80 \%$ wartości sprzedaży;

- grupe B stanowią towary obejmujące 30 - 35\% pozycji i stanowią $15 \%$ wartości;

- do grupy C zalicza się towary obejmujące 45 - 50\% pozycji, które stanowią $5 \%$ wartości rozchodu.

Relację 20/80 należy traktować umownie, ponieważ w praktyce zazwyczaj wystąpią odchylenia od przyjętej reguły. Odmianą metody ABC jest analiza XYZ, która ułatwia podejmowanie właściwych decyzji. Metoda XYZ pozwala grupować zapasy towarów według regularności popytu.

\section{ZAKOŃCZENIE}

Właściwy wybór polityki zaopatrzenia jest niezmiernie ważny w przedsiębiorstwie handlowym, wpływa bowiem na uzyskiwane przez niego wyniki ekonomiczne. Podstawowymi problemami w procesie zaopatrzenia są wybór dostawców, zarządzanie zapasami, właściwe magazynowanie towarów ${ }^{18}$. Racjonalne zakupy powinny zapewnić dostosowanie oferty przedsiębiorstwa do potrzeb rynku, obniżenia kosztów zakupu przez negocjowanie cen, prawidłową organizację dostaw oraz gospodarkę zapasami ${ }^{19}$. Należy również podkreślić rangę stabilności i pewności dostaw, która zapewnia stałą dostępność towarów. Przyjęta polityka zakupów jest zatem ważnym elementem w strategii działania przedsiębiorstwa handlowego. Właściwie zorganizowany $\mathrm{i}$ zarządzany proces zaopatrzenia $\mathrm{w}$ towary $\mathrm{z}$ pewnością wpłynie na zwiększenie rentowności sprzedaży, redukcję kosztów, szybkie i właściwe przekazywanie informacji, efektywność działania pracowników oraz poprawę wizerunku firmy. Dlatego też przy obecnej konkurencji, przedsiębiorstwa handlowe nie mogą pozwolić sobie na zaniedbania i nieefektywność działania w tym obszarze. Potrzebna jest zatem ciąła kontrola tej sfery działalności przedsiębiorstwa.

\footnotetext{
15 A. Zacirka, Zarzqdzanie zapasami $i$ dystrybucja asortymentu spawalniczego w BOC Gazy, „Logistyka” 2003/1, s. 34-35.

${ }^{16}$ W. Weiss, Optymalizacja poziomu zapasów - zrób to sam, „Logistyka” 2002/4, s. 56-58.

${ }^{17}$ B. Śliwczyński, Controlling w zarzqdzaniu logistyka, Wyższa Szkoła Logistyki, Poznań 2007, s. 352 - 355.

${ }^{18}$ M. Sławińska, Zarządzanie przedsiębiorstwem handlowym, PWE, Warszawa 2002, s.71.

${ }^{19}$ S. Wesołowski, Zmiany w ekonomice i organizacji zakupu, „Gospodarka Materiałowa i Logistyka” 1997/4, s. 84.
} 


\section{LITERATURA}

[1] Blaik P., Logistyka. Koncepcja zintegrowanego zarzadzania. PWE, Warszawa 2001.

[2] Ciesielski M., Strategie logistyczne przedsiębiorstw, WAE w Poznaniu, Poznań 1998.

[3] Cox R., Brittain P., Zarzqdzanie sprzedażq detaliczna, PWE, Warszawa 2000.

[4] Dudzik M. T., Zakup czy produkcja własna?, „Gospodarka Materiałowa i Logistyka” $1997 / 2$.

[5] Maternowska M., Analiza kosztów logistycznych wspomaga proces podejmowania decyzji w sferze dystrybucji - studium przypadków, „Logistyka” 2002/4.

[6] Nowicka - Skowron M., Efektywność systemów logistycznych, PWE, Warszawa 2000.

[7] Skowronek Cz., Wplyw procesów zaopatrzenia i gospodarowania materiałami na wyniki ekonomiczne przedsiębiorstwa, „Gospodarka Materiałowa i Logistyka” 1997/1.

[8] Skowronek Cz., Sarjusz - Wolski Z., Logistyka w przedsiębiorstwie, PWE, Warszawa 1999.

[9] Sławińska M., Zarzq̨dzanie przedsiębiorstwem handlowym, PWE, Warszawa 2002.

[10] Szczepankiewicz W., Obsluga logistyczna sektora handlu. Uwarunkowania $i$ kierunki zmian, WAE w Krakowie, Kraków 2002.

[11] Szczepankiewicz W., Organizacja źródet zaopatrzenia i rola handlu detalicznego w kanałach rynku, [w:] Handel detaliczny. Funkcjonowanie i kierunki rozwoju, red. Szumilak J., Oficyna Ekonomiczna, Kraków 2004.

[12] Śliwczyński B., Controlling w zarządzaniu logistyka, Wyższa Szkoła Logistyki, Poznań 2007.

[13] Weiss W., Integracyjna rola zarzqdzania zapasami, „Logistyka” 2003/1.

[14] Weiss W., Optymalizacja poziomu zapasów - zrób to sam, „Logistyka” 2002/4.

[15] Wesołowski S., Zmiany $w$ ekonomice $i$ organizacji zakupu, „Gospodarka Materiałowa i Logistyka" 1997/4.

[16] Zacirka A., Zarzqdzanie zapasami i dystrybucja asortymentu spawalniczego w BOC Gazy, ,Logistyka” 2003/1.

\section{SUPPLY PROCESS IN A COMMERCIAL ENTERPRISE}

The article concerns of the supply process problems in the commercial enterprise. It presents the main tasks of the purchase process and decision problems being in them. The article also shows the strategy of supplies applied in enterprises.

Keywords: supply, decission problems, tasks of purchase process, strategies.

DOI:10.7862/rz.2012.einh.29 